\title{
Interpretation of Religious Architecture Symbols in a Communicative Space of Religious Feasts
}

\author{
Natalia Mostitskaya \\ Moscow State Institute of Culture \\ Moscow, Russia \\ e-mail: mozt@rambler.ru
}

\begin{abstract}
This article justifies the methodological principles which consider the elements of festive communication and ritual action as the necessary conditions for the interpretation of religious architecture symbols. As an example there are represented methods of interpretation of religious architecture symbols of the Ancient Acropolis and Sophia of Constantinople (Hagia Sophia). The article discusses the specifics of the artistic image designing as virtual reality, directly focused on the process of transcendence as a way of a human's harmonizing with the universe, society and own individuality.
\end{abstract}

Keywords-feast; interpretation; festive communication; religious architecture; transcendence; reality; intentionality Introduction

\section{INTRODUCTION}

The dialogue between the viewer and the artwork has been explored by many scholars of the humanities. Even in antiquity, Socrates claimed that the moral principle «aretê» forms thanks to the art. Contemplation of beautiful forms creates beautiful thoughts and understanding of artwork idea allows a person to "get into the world of ideas" that makes the viewer more perfect and a partaker of the divine. Maintaining the creative and sacred dialogue with the world of the gods was one of the most important tasks of all cultures of the ancient world, as well as in the Middle Ages, but since the Modern Age the western culture intellectual elite of society culture changed the orientation of the sacred communication and rushes to the knowledge of the scientific picture of the world, involving other relations and forms of communication. Spiritual communicative practices were formed within the confines of religious worldview, they are known to us as rituals and ceremonies, prescribing symbolically and in a strict order of communication which took place in an aesthetically designed space. Therefore, religious art can be considered as a symbolic language which provides a sacred communicative connection.

Considering the basic function of religious art oriented on a dialogue with the transcendent reality it is correct to use the term of "art" as "techne" (technology, skills), proposed by Aristotle. Antiquity researcher A. F. Losev noted that in the understanding of the ancient Greeks, ""craft", art is not only human but also divine, cosmological. Universe - it is also the greatest "techne"... "Techne" - is at first, craft, secondly, art, and, thirdly, science "[9]. The artist in the ancient world was not only a craftsman but scientist and philosopher. This life experience strongly reflected in the meaning of the word art.

In contemporary philosophy of postmodernism, art is seen as an era priority discourse because signs of art language recreate the new reality as the semiotic model of the world. Questions of reality designing raised the interest of many researchers in the fields of philosophy, cultural studies, sociology, philology, art history, and therefore they are exposed through various methodological orientations. In order to discuss the interpretation of the religious architecture symbols this article proposes to use the theory of postmodernism, existentialism, and philosophical concepts of visual thinking by V. I. Zhukovsky [6] and D.V. Pivovarov

\section{INTERPRETATION OF AN ARTWORK}

The process of interpretation is associated with the disclosure of the text's meaning and provides its understanding. In postmodern philosophy [12] the possibility of subjective text reading is proclaimed (Roland Barthes, Jacques Derrida), and so the dialogue of the viewer and the artwork is considered as a creative act of designing one's own artistic image and reality based on own experience. At the same time there is a certain set of signs in culture by which a description of the basic sacred values is realized, and therefore interpretation within the confines of this culture is carried out with a focus on common patterns. The viewing of a foreign cultural era text, of course, is faced with the problem of adequate translation into your language, but researchers identify here the presence of "such characteristics that determine or at least allow multiple interpretations ..." [8. S. 430]. Feast as a cultural phenomenon appears as the cultural code which allows different interpretations coexist, while retaining sacred integrity at the set of all symbols and sings. Therefore, to get closer to the historical reading of the text which is hidden in architecture symbolism, readable in the process of motion of the construction, it is necessary to consider the ritual movement outside and inside the architectural space as a symbolic element of the festive ceremony.

One of the original names of festive events in Hebrew sounded like a "hag", from the verb "hagag", meaning "to dance." Experts [4] attributed its origin to the festive ceremonies performed to the rhythm of dance around the altar. Thus, understanding the holiday as a movement to the 
temple's sacred center and around the altar, allows the constructive elements of architecture to be interpreted in correlation with basic religious ideas. The architecture in this case acts as a "carrier" to the sacred world of values, thanks to the human capacity for interpretation, symbolization and transcendent staying in virtual reality.

\section{COMmunicative SPace of a Feast or Virtual REALITY}

Festive communicative space [11] involves the designing of the particular emotional status that displays a person beyond the everyday life to the new reality, for which the transcendence experience is becoming relevant. Communication with the world of spiritual beings living under the laws of another world is the undoubted experience of a religious feast.

The concept of "reality" in the postmodern interpretation includes axiological living through the individual experience in any form of "symbolic life" [13]. Linguistic creativity is the basis of our life; it defines motivation and emotional reaction to the events of the world. Postmodernism considers the existence of multiple realities, each of which has its own symbolism of form and signs and designs perception of the world. All language realities exist in our minds and make a kind of a prism of the world perception, thanks to which the focus on certain objects is realized and these objects are interpreted by humans, according to their basic values and are included in the complete image of their picture of the world. In the philosophy of Husserl [3] this procedure is described by the term "intentionality" and means the process of consciousness, the living through the subject, the tendency of consciousness to specific subjects, which is directly concerning the analysis of the object's essence, giving it a meaning or interpretation. This creative act of consciousness is carried out thanks to the human capacity for transcendence and inherently also transcendental.

The communicative space of religious feast is revealed through the world of objects and symbolic language, with the main purpose of gaining experience of transcendence and the designing of a sacred reality. The feast as a cultural phenomenon is called to consolidate the society on common values and at the same time, as noted by culture experts, "characteristic feature of any feast is precisely its relationship with the sphere of the sacred" [10. S. 134-135]. This relationship is primarily spiritual, and therefore it is recreated in the interpretation process of ritual language symbols and art forms. Therefore, the author of architectural work directly constructs a sphere of sacred reality and the reading and interpretation of the symbols is carried out thanks to intentional focus on the most striking elements of reality, in particular, on the architectural constructions or decor.

The key elements of the analysis for a modern researcher studying the work of architecture as a historical artifact and text should be the sacred ritual of communication with the world of the gods directly occurring in a given space. Exploration of the festive culture fully unlocks the meaning of all constituent elements of the ritual and on this basis allows analyzing the symbolic forms of artwork which emphasizes the attention of ceremony participants on the rhythms of ritual actions and key moments of emotional experiences of celebratory events as virtual space.

The architect is an author of artistic construction in a strictly ritual and ceremonial sequence as he draws the audience's attention to specific constructive or decorative architectural elements, symbols that reveal the general idea of a feast. The intentional focus sequential decoding of these symbols allows the participants of celebratory event to recreate the image of the sacred reality and to get a transcendental experience.

In order to understand the meaning of an artwork as modern researcher of architectural masterpiece or as modern audience it is necessary to consider the steps of the sacred dialogue of festive ritual. This approach will help to direct the viewer's attention to the important constructive features of the architectural space and recreate a complete image of the artwork.

According to art historian B. Vipper [2], any architectural work is revealed in the process of movement on the construction and in perception of the building scale as it relates to the own size of a man. But for a person exploring the architecture only on the basis of photographs and figures this procedure is not possible; however, the ability to construct a symbolic space of another reality allows us to recreate a physical representation of the building and its virtual existence in the sacred spiritual space.

\section{WAYS TO INTERPRET THE SIGNS' ELEMENTS OF THE ACROPOLIS OF ATHENS AND HAGIA SOPHIA}

Let us illustrate this thesis by the example of the architectural complex of the Acropolis of Athens (the main temple dedicated to Athena - The Parthenon) and the Temple of Sophia of Constantinople (now Hagia Sophia in Istanbul). These temple buildings were originally built as a space for sacred communion, and therefore all the symbolic elements of architectural constructions are conformed to this basic idea. Despite the fact that the Parthenon and Sophia demonstrate different religious outlooks it is possible to identify some common features. Athena, wisdom of Zeus, born from the head of Zeus, and Sophia, Wisdom of God as a natural property of God the Creator, are "the bearing bosom of God, the storage of ever-being prototypes and samples" [1]. Therefore, the main task of creating communicative space is to join this wisdom, Universal Logos, as the Universe or the One God, and to become part of it. A man solves the problem of reunification with the absolute primary source of being. Architectural elements in this case are the function of signs, labels, focusing a human on this reunion and harmonize him with society and universe.

The communicative space of Acropolis of Athens reveals its symbolic language in the festive event of the Great Panathenaea [7] - "a feast for all the Athenians", dedicated to the birthday of Athena. In order to consider the space of Hagia Sophia it is important to learn the celebration of the Paschal Liturgy.

Let us note the most important points for interpretation of architectural symbols in a comparative description of the 
feasts. Firstly, all the citizens of the polis/city were taking part in a ceremony.

Secondly, in the antique temple sacrifices were made on the site of the eastern part of the Acropolis before the eastern facade of the Parthenon by kindling a large fire as well as directly in the temple before the statue of Athena, where only priests could enter. In Hagia Sophia symbolic sacrifice were made at the altar - located in the eastern part of the temple where all the believers were not allowed but only the priests. Each of the cult spaces is indicated by a special place, symbolizing the sacred space where only dedicated were allowed to enter.

Third, in the ancient Panathenaea feast just before the last day of celebration a ritual procession started from the main gate, the procession then stopped on the main square and the last stop was at the eastern facade of the Parthenon on the Acropolis hill. Thus, the architectural complex of the Acropolis with its higher location point was geographically separated from the whole city symbolizing a sacred idea of the Greek universe.

It is possible to reconstruct the ritual movement in Hagia Sofia through the remaining Orthodox traditions, so the festive ceremony assumes few variants with different members of the movement. The first is the movement of the whole procession with the priests around the temple, stopping in front of the temple and entering the temple with all believers. The movement of the clergyman with chandelier on the inner perimeter of the temple was supposed to include all the parishioners in the general ring, as well as the movement of priests around the altar and toward the flock, and even the movement of the flock around the central icon and between the lectern and priests in the sacrament of initiation to the Sacrificial Gifts. Thus, we got a scheme of movement in the temple, which resembles the figure eight, inscribed in a circle.

As we explore the structural elements of the festive event let us name the architectural elements and parts of the complex which reveal the symbolism and meaning of the movement and its task which was in participant's living through the virtual reality events.

In antiquity, climbing to the Acropolis, the procession passed through the entrance called Propylaea. These gates of the architectural complex functioned as a kind of preparation of procession participants to meet the shrine. This preparation was in passing through the gallery of fine arts where artworks were "entering" viewers in a different space through constructing an ideal world by the language of artistic images. Onwards, a small square with a statue of Athena was opened to the gaze of the procession, and maybe there was a short stop in front of it to greet the goddess and have a pause before the most responsible movement to the altar, the Parthenon. Before the western façade, the procession was divided by passing the Parthenon on both sides and closed up around the eastern facade of the Parthenon. The procession movement and the designing of a sacred space virtual reality increased the elements and constructive features of the building: the "heroic scale of the building" is a characteristic of the Parthenon proportions which allowed a person to feel like a "hero" [5], who is permitted to enter into the realm of the gods; columns' flutes thanks to checkered light and shade provided dynamics to the construction "including" a procession; the relief on the zoophorus depicting the entire procession, but in an ideal space and as an ideal for walking people; and the decorative rhythm of the zoophorus reliefs at the same time set the dynamics of the procession movement. Thus, the construction of the Parthenon allowed uniting the whole society into one body, an universal body with its characteristics of integrity, which was the most important task of the temple, symbolically holding and visualizing the balance and order in of the universe.

The spherical dome of Hagia Sofia deserves special attention, it is cut with the raw of windows, so that on a sunny day piers between the windows are almost invisible. It creates the illusion of a giant hoop hanging over the believers. The circle form is repeated many times and in different scale in the elements of the arch structure and in the form of giant chandeliers. Thanks to such figures in architecture a person is offered the opportunity to feel like they are in a spherical space, and the participation in the collective motion in a circle introduces them to a state of trance or immersion in a transcendent reality, the essence of which is the Bosom of God. Thus, the universe is also represented here, in contrast to the impersonal but inherited gods' universe of antiquity, whereas the Christian universe is God himself, and this nuance can also be read in the symbolism of architecture.

\section{CONCLUSION}

The interpretation of the symbolism of cult architectural space is traditionally carried out by analyzing the basic values of its culture, revealing the specificity of historical understanding of the essential characteristics of a transcendent reality and the main goals of the society. Using this approach, it is necessary to additionally consider the fact that architecture as a symbolic text of huge volumes and forms can be read during the movement on the construction and correlation of its scales with the own feelings of a man. At the same time all the diversity of ritual movements in the temple, as well as the synthesis of value systems of this culture are concentrated in the festive ceremony, and therefore the learning of festive events and ritual acts let us interpret the features of a symbolically represented communicative space of a religious building with high accuracy.

\section{REFERENCES}

[1] V. Aksyuchits, Sofia heaven and earth. / Under the shadow of the cross //http://www.regels.org/God-Trinity-Sophia.htm

[2] B. Vipper, Introduction to the historical study of art. - Moscow, 1985.

[3] E. Gusserl, Selected works / Comp. V. A. Kurennoy. - Moscow, 2005.

[4] K. Zhigulsky, Festival and culture. - Moscow, 1985.

[5] V. Zhukovsky, The Parthenon /Formula harmony. - Krasnoyarsk, 2001.

[6] V. Zhukovsky, D. Pivovarov Intelligent visualization entities. Krasnoyarsk, 1998.

[7] F. Zelinsky, The history of ancient culture. - St. Petersburg, 1995. 
[8] G. Lesskis, The syntagmatics and paradigms of literary text // Izvestiya AS USSR. Series literature and the language.V.41, 1982, № 5. P. 430.

[9] A. Losev, Twelve theses on classical culture// "Student Meridian", 1983, vol. 9-10.// URL:http://psylib.org.ua/books/_losew02.htm

[10] A. Pigalev, Festival / Cultural studies of the twentieth century. Encyclopedia. V.2.. - St. Petersburg, 1998. pp. 134-135.

[11] V. Remizov, V. Sadovskaya, The basic communicative culture.Moscow, 2011.

[12] K. Rogova, A modern interpretation of a literary text // URL:http://slaviccenters.duke.edu/uploads/media_items/2rogova.orig inal.pdf

[13] V. Rozin, Culturology. - Moscow, 2003. 